TERMINUS

t. 20 (2018), z. 1 (46), s. 1-30

doi: $10.4467 / 20843844$ TE. 18.001 .8936

www.ejournals.eu/Terminus

Radosław Jakubczyk

http://orcid.org/0000-0001-5642-1611

Kraków

radoslaw.jakubczyk@wp.pl

\title{
Sprawa honoru albo o męskości w staroislandzkich sagach rodowych
}

\begin{abstract}
A Matter of Honor. On Masculinity in the Old Icelandic Family Sagas

The paper deals with the concept of masculinity in selected 13th-century Icelandic family sagas (Íslendingasögur). The author argues that the then ethos of aggressive masculinity, based on such values as honor, vengeance, subordination of women, and supremacy over other masculinities, oppressively influenced men who wanted to meet the exorbitant demands of medieval Icelandic society in order to avoid social stigmatization and accusations of effeminacy. The author refers to the notion of "hegemonic masculinity", a concept proposed by Raewyn Connell in her influential book Masculinities. In the paper, the model of hegemonic masculinity, characterized by the desire to sanction patriarchy and male domination, is confronted with other types of masculinities (subordinate and marginalized masculinities). Therefore, the following issues are also discussed: male initiation and code of honor, violence against women, emotions of the saga protagonists. The author concludes that unwritten orders and prohibitions that were supposed to protect men from dishonor and loss of social position contributed to a repressive system based on heroism and violence.
\end{abstract}

Keywords: masculinity, honor, vengeance, family sagas, medieval Iceland 
W jednym ze swoich artykułów Helga Kress określiła staroislandzkie sagi mianem "męskiej literatury” (masculine literature), mając na względzie nie tyle krąg czytelniczych odbiorców, ile stopień zmaskulinizowania świata przedstawionego tych dzieł. Jeszcze dalej poszła Jóhanna Katrín Friðriksdóttir, która w kontekście androcentryzmu dawnej literatury islandzkiej mówi o „męskości hegemonicznej” (hegemonic masculinity) oraz „kulturze macho” (macho culture). Tym tropem podąża również John Stephens, stawiając trafną tezę o „patriarchalnej strukturze” (patriarchal structure) islandzkiego społeczeństwa doby średniowiecza, a także Carol J. Clover, pisząc o ówczesnej „binarności społecznej” (social binary) ${ }^{1}$, zakładającej podział na silnych mężczyzn (w tej grupie znajdują się również „męskie” kobiety) i całą resztę społeczeństwa, czyli: kobiety, dzieci, starców, „niemęskich” mężczyzn, niewolników etc. Tego typu orzeczenia, wskazujące dobitnie i jednoznacznie na prymat mężczyzn w średniowiecznej Islandii, można by rzecz jasna mnożyć, a każdy głos kontestujący taki stan rzeczy należałoby, jak się wydaje, uznać za nadużycie.

Rzecz paradoksalna, że kwestia staroislandzkiej męskości (czy może raczej: staroislandzkich męskości) jeszcze do niedawna nie była zbyt często rozważana, jeśli nie liczyć odkrywczego, acz opartego jedynie na wybranych przykładach, studium Prebena Meulengrachta

1 Kolejne przytoczenia: H. Kress, "You will find it all rather monotonous". On Literary Tradition and the Feminine Experience in Laxdoela saga, w: The Nordic Mind. Current Trends in Scandinavian Literary Criticism, ed. by F.E. Andersen, J. Weinstock, Lanham 1986, s. 181; J.K. Friðriksdóttir, Gender, Humor, and Power in Old Norse-Icelandic Literature, w: Laughter, Humor, and the (Un)Making of Gender. Historical and Cultural Perspectives, ed. by A. Foka, J. Liliequist, New York 2015, s. 214; J.K. Friðriksdóttir, Gender, w: The Routledge Research Companion to the Medieval Icelandic Sagas, ed. by Á. Jakobsson, S. Jakobsson, New York 2017, s. 231; J. Stephens, The Unwelcome Suitor. Patriarchal Norms, Masculine Inefficiency, and Negative Modelling in the Old Icelandic Kormáks saga, „Parergon” 2 (1992), s. 162; C.J. Clover, Regardless of Sex. Men, Women, and Power in Early Northern Europe, „Representations” 44 (1993), s. 13. 
Sørensena o dyshonorze w dawnej literaturze islandzkiej², szkiców Carla Phelpsteada o roli zarostu i penisa w średniowiecznej Islandii ${ }^{3}$ czy artykułów Ásdis Egilsdóttir ${ }^{4}$ oraz Ármanna Jakobssona ${ }^{5}$ na temat męskiej tożsamości w pojedynczych sagach. Wprawdzie impas przerwał Gareth Lloyd Evans, który w swojej rozprawie doktorskiej podjął próbę usystematyzowania tego zagadnienia na kanwie kilkunastu sag rodowych ${ }^{6}$, lecz owa problematyka w dalszym ciągu, jak można sądzić, daje szerokie pole do badawczych eksploracji.

Jak zgodnie utrzymują uczeni, w dominującym staroislandzkim modelu męskości, opierającym się na dążeniu do podporządkowania kobiet i supremacji nad innymi mężczyznami, najwyższą wartość stanowił honor, nie tylko własny, lecz także całego rodu, a elementarną męską powinnością była jego obrona, nawet za cenę życia ${ }^{7}$. Stawką nieustannej gotowości do obrony honoru, bądź to $\mathrm{w}$ wymiarze indywidualnym, bądź też wspólnotowym, była konieczność ciągłego potwierdzania swojej męskości, rozumianej jako zdolność do

2 P. Meulengracht Sørensen, The Unmanly Man. Concepts of Sexual Defamation in Early Northern Society, transl. by J. Turville-Petre, Odense 1983.

3 C. Phelpstead, Hair Today, Gone Tomorrow. Hair Loss, the Tonsure, and Masculinity in Medieval Iceland, „Scandinavian Studies” 1 (2013); idem, Size Matters. Penile Problems in Sagas of Icelanders, „Exemplaria” 3 (2007).

4 Á. Egilsdóttir, Masculinity and/or Peace? On Eyrbyggja saga’s Máhlỉingamál, w: Frederic Amory in Memoriam. Old Norse-Icelandic Studies, ed. by J. Lindow, G. Clark, Berkeley 2015.

5 Á. Jakobsson, Masculinity and Politics in Njáls saga, „Viator” 38 (2007). Zob. też R. Jakubczyk, „Wielu, co go widzi, nie wie, czy to chłop czy niewiasta”, czyli o (nie) męskości w staroislandzkiej Sadze o Egilu i Sadze o Njalu, „Przegląd Humanistyczny” 2 (2018).

6 G.L. Evans, Models of Men. The Construction and Problematization of Masculinities in the Îslendingasögur, University of Oxford 2015 (niepublikowana praca doktorska).

7 Zob. W.I. Miller, Humiliation and Other Essays on Honor, Social Discomfort, and Violence, Ithaca 1995, s. 116; P. Meulengracht Sørensen, Social Institutions and Belief Systems of Medieval Iceland (c. 870-1400) and Their Relations to Literary Production, w: Old Icelandic Literature and Society, ed. by M. Clunies Ross, Cambridge 2000, s. 23. 
stosowania przemocy i natychmiastowego powzięcia odwetu, w obawie przed wykluczeniem z grona „prawdziwych” mężczyzn oraz społeczną marginalizacją. Spoczywający na przedstawicielach płci męskiej nakaz zemsty rodowej oraz narzucony etos męskości, nader surowy w swoich założeniach i oparty na rygorystycznym pojmowaniu ról płciowych, opresyjnie oddziaływał na samych mężczyzn, którzy za wszelką cenę usiłowali sprostać wymaganiom stawianym przez średniowieczne społeczeństwo islandzkie ${ }^{8}$. Trzeba bowiem mieć na uwadze fakt, że wszelkie działania i zachowania nienormatywne, a więc niezgodne $\mathrm{z}$ dominującym wariantem męskości, narażały męski honor na szwank, a niekiedy wręcz okrywały mężczyznę hańbą (níð)9.

Odwołując się do społecznej teorii płci autorstwa Raewyn Connell, wyłożonej w paru miejscach, a bodaj najpełniej w studium $M a-$ sculinities, wydanym po raz pierwszy w 1995 roku $^{10}$, której głównym, by nie rzec sztandarowym, założeniem jest, jak wskazuje sam tytuł książki, istnienie tyleż jednej uniwersalnej męskości, co wielu różnych jej odmian, ów dominujący i najczęściej praktykowany przez mężczyzn w średniowiecznej Islandii wariant można by określić mianem "męskości hegemonicznej" ${ }^{11}$. Model ten zakłada, ujmując rzecz skrótowo, hegemonię zewnętrzną oraz wewnętrzną, czyli dominację nad kobietami i innymi męskościami ${ }^{12}$, a jego fundamentalnymi wyznacznikami są: heroizm, autonomia, dążenie do uzyskania

8 Zob. Á. Jakobsson, Masculinity..., s. 214.

9 Szerzej pisze na ten temat m.in. F. Ström, Nið, ergi, and Old Norse Moral Attitudes, London 1973.

10 Korzystam z wydania drugiego: R. Connell, Masculinities, Berkeley 2005.

11 Ibidem, s. 77. Nawiasem mówiąc, we wcześniejszej o kilka lat książce termin ten został użyty m.in. w kontekście bohaterów sag (R. Connell, Gender and Power. Society, the Person and Sexual Politics, Cambridge 1987, s. 249). Zob. też R. Connell, J.W. Messerschmidt, Hegemonic Masculinity. Rethinking the Concept, „Gender and Society" 6 (2005).

${ }_{12}$ Zob. D.Z. Demetriou, Connell's Concept of Hegemonic Masculinity. A Critique, „Theory and Society” 30 (2001), no. 3, s. 341. 
władzy i wysokiej pozycji społecznej, agresja i skłonność do używania przemocy, a jednocześnie opanowanie, powściągliwość w okazywaniu emocji oraz dystans ${ }^{13}$. Męskość hegemoniczna, definiowana przez Connell jako zbiór praktyk służących usankcjonowaniu patriarchatu i męskiej dominacji ${ }^{14}$, jest modelowym wzorcem, ideałem męskości konstruowanym i przetwarzanym przez społeczeństwo. Connell wyróżnia nadto inne warianty męskości, oparte na relacji przyzwolenia (authorization) oraz współudziału (complicity), które w mniejszym lub większym stopniu czerpią korzyści z patriarchatu ${ }^{15}$, lecz nie przejawiają niektórych cech bądź zachowań typowych dla męskości hegemonicznej, stąd też są jej podległe.

W niniejszym tekście pragnę przyjrzeć się strategiom konstruowania męskości w wybranych staroislandzkich sagach rodowych. Interesować mnie będzie zwłaszcza sposób, w jaki ówcześni mężczyźni myśleli, działali, wyrażali uczucia i zbijali „męski kapitał” (masculine capital) ${ }^{16}$ - by nawiązać do nośnego terminu ukutego blisko dekadę temu przez Erica Andersona - pozwalający uzyskać dominującą pozycję w społeczeństwie. W centrum zainteresowania znajdzie się zarówno model męskości hegemonicznej, jak i męskości zmarginalizowane i podporządkowane, innymi słowy: symbolicznie wykluczone i stygmatyzowane społecznie ze względu na przejawianie „niemęskich" cech lub zachowań. Analiza ograniczy się wyłącznie do kilku sag rodowych, pominięte zostaną natomiast inne podgatunki sag, tworzone mniej więcej w tym samym czasie, które mogłyby stanowić jeden $\mathrm{z}$ możliwych kontekstów interpretacyjnych ${ }^{17}$.

13 Zob. M. Donaldson, What is Hegemonic Masculinity?, „Theory and Society” 22 (1993), no. 5 (special issue: Masculinities), s. 644.

14 R. Connell, Masculinities, s. 77.

15 Ibidem, s. 79-81. Connell nazywa to zjawisko „dywidendą patriarchalną” (patriarchal divident).

16 E. Anderson, Inclusive Masculinity. The Changing Nature of Masculinities, New York 2009, s. 42.

17 Myślę tu chociażby o sagach wchodzących w skład kompilacji o rodzie Sturlungów (Sturlunga saga). O honorze w tejże kompilacji pisze w ogólnych zary- 
$\mathrm{Na}$ wstępie należy przypomnieć, że sagi rodowe (family sagas), alternatywnie określane również sagami o Islandczykach

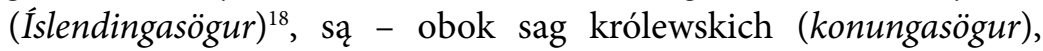
współczesnych (samtíðarsögur), rycerskich (riddarasögur), biskupich (biskupasögur) i legendarnych (fornaldarsögur) - jednym z podgatunków piśmiennictwa staroislandzkiego. Tłem sag rodowych są najczęściej wydarzenia między 930 a 1030 rokiem, a więc końcowe etapy zasiedlenia wyspy, ustanowienie zgromadzenia ogólnego (Alpingi), przyjęcie chrześcijaństwa przez Islandczyków i wykształcenie się ustroju politycznego zwanego bjóðveldi ${ }^{19}$. Owe zdarzenia znajdują rzecz jasna oddźwięk w wielu sagach, jednakże ich centralnym tematem są konflikty pomiędzy protagonistami bądź całymi rodami, rozwiązywane zazwyczaj zbrojnie ${ }^{20}$. Strukturę owych opowieści można podzielić na sześć części: wstęp, konflikt, kulminacja, zemsta, ugoda, następstwa ${ }^{21}$. Do sag rodowych zalicza się obecnie czterdzieści utworów ${ }^{22}$, począwszy od najobszerniejszej, skomponowanej ze stu pięćdziesięciu rozdziałów, Sagi o Njalu (Njáls saga) ${ }^{23}$,

sach R. Bauman, Performance and Honor in $13^{\text {th }}$-Century Iceland, ,The Journal of American Folklore" 392 (1986).

$18 \mathrm{~W}$ sprawie sag rodowych zob. m.in.: T.M. Andersson, The Icelandic Family Saga. An Analytic Reading, Cambridge 1967; idem, The Growth of the Medieval Icelandic Sagas (1180-1280), New York 2006; C.J. Clover, Icelandic Family Sagas, w: Old Norse-Icelandic Literature. A Critical Guide, ed. by C.J. Clover, J. Lindow, New York 1985; V. Ólason, Family Sagas, w: A Companion to Old Norse-Icelandic Literature and Culture, ed. by R. McTurk, Malden 2005; R. Gogosz, Sagi o Islandczykach, w: Sagi islandzkie. Zarys dziejów literatury staronordyckiej, red. J. Morawiec, Ł. Neubauer, Warszawa 2015.

19 Zob. K. Hastrup, Culture and History in Medieval Iceland. An Anthropological Analysis of Structure and Change, Oxford 1985.

20 Zob. T.M. Andersson, The Icelandic Family Saga, s. 11.

${ }^{21}$ Podział ten zapożyczam od Theodore’a M. Anderssona (ibidem, s. 6-30).

22 Zob. V. Ólason, Family Sagas, s. 114-115. Co symptomatyczne, ponad połowa sag ma w tytule postać męską. Tylko jedna - Saga o synach Droplaug (Droplaugarsonar saga) - ma w tytule postać kobiecą.

${ }^{23}$ Wielu uznaje Sagę o Njalu za najwybitniejszą islandzką sagę rodową. William Paton Ker określił ją niegdyś mianem „najwspanialszej ze wszystkich sag” (W.P. Ker, Epic and Romance. Essays on Medieval Literature, New York 1897, s. 218). 
a na krótkiej, kilkunastostronicowej Sadze o Ölkofrim (Ölkofra saga) skończywszy. Zostały one spisane w głównej mierze w XIII wieku, a ich autorzy są najczęściej anonimowi, wyjąwszy może Sagę o Egilu (Egils saga), której autorstwo przypisuje się - choć kwestia to dyskusyjna - Snorriemu Sturlusonowi (1179-1241)24. Skądinąd Snorri został uznany przez niektórych badaczy (między innymi przez Jónasa Kristjánssona ${ }^{25}$ ) za inicjatora procesu tworzenia sag rodowych w średniowiecznej Islandii. O ile trudno dziś wskazać ze stuprocentową pewnością najstarszą sagę rodową, o tyle za najmłodszą uznaje się powszechnie Sage o mieszkańcach Fljotsdalu (Fljótsdæela saga), spisaną najprawdopodobniej na przełomie XV i XVI wieku ${ }^{26}$. Specyficzna natura tych dzieł, wiążąca się $\mathrm{z}$ faktem, że tworzono je kilkaset lat po opisywanych w nich wydarzeniach, może zresztą budzić zasadne wątpliwości co do ich faktograficznej wiarygodności. Sagi rodowe zachowały się w licznych średniowiecznych manuskryptach, a także w późniejszych o kilka wieków odpisach. Najbardziej znanym średniowiecznym rękopisem, zawierającym jedenaście sag rodowych, jest Möðruvallabók (AM 132 fol.) z pierwszej połowy XIV stulecia ${ }^{27}$. Pierwsze edycje sag rodowych ukazały się w 1756 roku w Hólar, gdzie

${ }^{24}$ Za taką atrybucją optowało wielu badaczy: Björn Magnússon Ólsen, Sigurður Nordal, Peter Hallberg czy Vésteinn Ólason. Obecnie nie brak jednak coraz śmielszych głosów podających tę hipotezę w wątpliwość. W tym duchu wypowiedział się np. K.J. Wanner, Snorri Sturluson and the Edda. The Conversion of Cultural Capital in Medieval Scandinavia, Toronto 2008, s. 26.

25 Zob. J. Kristjánsson, Var Snorri Sturluson upphafsmaður Íslendingasagna?, „Andvari” 32 (1990), s. 85-100.

26 Zob. W. Sayers, Principled Women, Pressured Men. Nostalgia in Fljótsdæla saga, „Reading Medieval Studies” 22 (1996), s. 21.

27 Manuskrypt wziął swą nazwę od gospodarstwa Möðruvellir w Eyjaförður. Składa się z dwustu kart i niemal w całości został spisany przez jednego skrybę. Pod koniec XVII wieku rękopis został przekazany przez rodzinę ówczesnego właściciela, Magnúsa Björnssona, do Kopenhagi, gdzie włączono go do zbiorów Árniego Magnússona. W 1974 roku manuskrypt powrócił na Islandię. 
znajdowała się jedna $\mathrm{z}$ dwóch, obok Skálholt, islandzkich diecezji ${ }^{28}$, a pierwsze tłumaczenia (m.in. na angielski, francuski i niemiecki) ogłoszono drukiem w XIX wieku ${ }^{29}$. Styl sag rodowych jest lapidarny, rzeczowy i pozbawiony odautorskiego komentarza, nawet gdy relacja dotyczy najbardziej dramatycznych wydarzeń.

\section{Męska inicjacja}

Analizując rytuały przejścia, w tym również różnorodne obrzędy inicjacyjne, Arnold van Gennep podzielił ich strukturę na trzy części: fazę preliminalną, związaną z wyłączeniem jednostki z danej społeczności, fazę liminalną, czyli krótko- lub długotrwały okres przejściowy pomiędzy dawną a przyszłą rolą społeczną, oraz fazę postliminalną, polegającą na uzyskaniu przez jednostkę nowego statusu i jej ponownym włączeniu do społeczności ${ }^{30}$. Powyższy schemat niejednokrotnie znajduje odzwierciedlenie w staroislandzkim ceremoniale wcielenia chłopców do grona mężczyzn, a za przykład niech tu posłuży, by ograniczyć się do najjaskrawszego, tytułowy bohater Sagi o Viga-Glumie i jego - nie do końca pomyślna, trzeba to od razu podkreślić - męska inicjacja. Warto dla jasności wywodu zarysować

${ }_{28}$ Wydano wówczas kilkanaście sag rodowych, m.in. Sage o Grettirze (Grettis saga Ásmundarsonar), Sagę o Gislim (Gísla saga Súrsonnar), Sagę o Viga-Glumie (Víga-Glúms saga), Sagę o sprzymierzonych (Bandamanna saga), Sagę o Viglundzie (Víglundar saga) oraz Sagę o Bardzie (Bárðar saga Snoefellsáss). Diecezja w Hólar została utworzona w 1106 roku, a jej pierwszym biskupem był Jón Ögmundarson.

29 Zob. H. Hermannsson, Bibliography of the Icelandic Sagas and Minor Tales, Ithaca 1908. Pierwsze polskie tłumaczenia wybranych sag rodowych - pióra Artura Górskiego - ukazały się w 1931 roku. Przekłady zostały oparte w przeważającej mierze na tłumaczeniach niemieckich, wobec czego Górski nie ustrzegł się niedociągnięć, zwłaszcza w przypadku sagowych eponimów i toponimów.

30 A. van Gennep, Obrzędy przejścia. Systematyczne studium ceremonii, przeł. B. Biały, Warszawa 2006, s. 36. 
tło wydarzeń tejże opowieści: piętnastoletni Glum ${ }^{31}$, utraciwszy majątek ojca i okrywszy się z tego powodu niesławą, opuszcza Islandię i wyrusza do Norwegii, zatrzymując się u swojego dziada, Vigfusa. Początkowo jest traktowany przez tamtejszą społeczność lekceważąco i z dezaprobatą, podczas uczty gospodarz przydziela mu najgorsze miejsce, jawnie okazując mu tym gestem brak szacunku ${ }^{32}$. Położenie Gluma zmienia diametralnie zabicie berserka, którym to czynem niejako naprawił własną reputację i zaskarbił sobie powszechne uznanie. Po tym wydarzeniu, poczytywanym za „demonstrację męstwa" (VG 22) ${ }^{33}$, Glum otrzymuje od Vigfusa drogocenny płaszcz, złotą włócznię oraz miecz, a następnie powraca na Islandię, gdzie odzyskuje rodowe włości i staje się osobą wpływową.

Schemat ten, który w ślad za Mirceą Eliadem można by określić mianem „inicjacji heroicznej” ${ }^{34}$, jest zatem następujący: młody bohater udaje się za granicę, gdzie - zrazu ignorowany i wyśmiewany dowodzi swojej odwagi czynem, zabijając berserka lub (jak ojciec Gluma, Eyjolf; VG 11) niedźwiedzia, utożsamianego zwykle z owymi wojownikami ${ }^{35}$, po czym otrzymuje w darze miecz, funkcjonujący

${ }^{31}$ W całym tekście stosuję spolszczony zapis imion bohaterów sag.

${ }_{32}$ W średniowiecznej Skandynawii miejsce przy stole zależało od sławy, statusu i zamożności. Goście majętni oraz cieszący się estymą zajmowali miejsca w ławach ustawionych najbliżej centrum (M.W. Williams, Social Scandinavia in the Viking Age, New York 1920, s. 319-320).

${ }_{33} \mathrm{~W}$ ten sposób oznaczam odniesienia do sag (cyfra po skrócie wskazuje numer strony): E = Saga o Egilu, przeł. A. Załuska-Strömberg, Poznań 1974; G = Saga o Gunnlaugu Wężowym Języku, przeł. A. Załuska-Strömberg, Wrocław 1968; GR = Grettis saga Ásmundarsonar, G. Jónsson gaf út, Reykjavík 1936 (IIF VII); H = Saga o Hallfredzie skaldzie kłopotliwym, wstęp i przeł. J. Morawiec, Wrocław 2011; HT = Saga o Hønsa-Thórim, przeł. F. Kuklewski, Sandomierz 2009; L = Saga rodu z Laxdalu, przeł. A. Załuska-Strömberg, Poznań 1973; N = Saga o Njalu, przeł. A. Załuska-Strömberg, Poznań 1968; VG = Saga o Viga-Glumie, przeł. Ł. Malinowski, Sandomierz 2010.

${ }_{34}$ M. Eliade, Rites and Symbols of Initiation. The Mysteries of Birth and Rebirth, New York 1975, s. 81.

35 Zob. M. Danielli, Initiation Ceremonial from Norse Literature, „Folklore” 2 (1945), s. 233. Badaczka ta wskazuje na podstawie analizy kilku sag, że pokonanie 
w sagach jako symbol falliczny i synonim władzy ${ }^{36}$, i powraca w rodzinne strony, by bronić honoru rodu oraz sprawować rządy nad dystryktem. W przypadku Gluma uzyskanie dojrzałości fizycznej nie idzie jednak w parze $\mathrm{z}$ akceptacją społeczną; choć protagonista, sportretowany przez twórcę sagi jako jednostka leniwa, nierozgarnięta, aspołeczna, a nawet szalona ${ }^{37}$, został włączony w poczet mężczyzn, to jednak nigdy nie stał się pełnoprawnym członkiem lokalnej społeczności, co w ostrych słowach komunikuje mu jeden z jego antagonistów: „Udajesz teraz wielkiego człowieka, Glumie, ale dla nas wydajesz się tym samym idiotą, jakim byłeś, zanim wyruszyłeś w świat" (VG 26).

Jak wspomniano, otrzymanie miecza było symboliczną cezurą, finalnym etapem procesu inicjacyjnego i wiązało się z osiągnięciem przez inicjowanego najwyższego stopnia dojrzałości i męskości. Toteż nie dziwi, że miecze są w sagach najpilniej strzeżonymi atrybutami, bohaterowie nadają im nazwy adekwatne do ich właściwości, przypisują im magiczną moc ${ }^{38}$, przechowują je z pietyzmem i nie odstępują

w walce berserka (a innymi słowy: silniejszego od siebie przeciwnika) było na ogół warunkiem sine qua non uzyskania statusu mężczyzny.

${ }_{36}$ H. Kress, Taming the Shrew. The Rise of Patriarchy and the Subordination of the Feminine in Old Norse Literature, w: Cold Counsel. Women in Old Norse Literature and Mythology, ed. by S.M. Anderson, K. Swenson, New York 2002, s. 90.

37 Oto charakterystyka Gluma: „[...] nie brał udziału w pracach na gospodarstwie i był raczej opóźniony w rozwoju. Był zawsze powściągliwy i małomówny, wysoki mężczyzna ze zniekształconymi brwiami, prostymi blond włosami, chudy i uważany raczej za tępaka; nie uczestniczył w społecznych zgromadzeniach" (VG 17). W innym miejscu saga opisuje jego niekontrolowany wybuch szaleńczego śmiechu: „[...] jego ciałem zawładnęły spazmy śmiechu. A chwyciły go tak bardzo, że jego twarz pobladła i łzy rozmiaru gradowych brył wypłynęły z jego oczu. Później często zachowywał się w ten sposób, gdy był w nastroju do zabijania" (VG 26). Na temat szaleństwa w literaturze staroislandzkiej zob. J.G. Høyersten, Madness in the Old Norse Society. Narratives and Ideas, „Nordic Journal of Psychiatry” 5 (2007).

38 Prym wiedzie w tym względzie Sköfnung, miecz, którym według legendy miał władać król Hrólf Kraki. Wzmianka o tym mieczu pojawia się m.in. w Sadze rodu z Laxdalu (rozdz. 57) oraz w początkowych rozdziałach Sagi o Kormaku (Kormáks saga). Broń ta była znana z magicznych właściwości: „[...] natura miecza 
ich na krok. Albowiem stratę miecza, niezależnie od okoliczności, uznawano wówczas za dyshonor i czyn dozgonnie dyskwalifikujący mężczyznę, a nawet za akt symbolicznej kastracji, z racji fallicznych konotacji owej broni. Boleśnie przekonuje się o tym chociażby Geirmund, bohater Sagi rodu $z$ Laxdalu (Laxdoela saga) ${ }^{39}$, tracąc bezpowrotnie swój miecz Rębacz Nóg, co gorsza, na rzecz kobiety (L 66).

$\mathrm{W}$ średniowiecznej Islandii kluczowe znaczenie $\mathrm{w}$ procesie socjalizacji chłopców do ról mężczyzn odgrywały pełne przemocy i brutalności gry i rozrywki, takie jak zapasy, walki koni czy zawody piłkarskie, podczas których „siłę męską wystawiało się na próbę” $(\mathrm{E} 77)^{40}$. Kształtowały one umiejętność walki z przeciwnikiem oraz stanowiły poligon doświadczalny dla młodych mężczyzn przed czekającymi ich w przyszłości krwawymi pojedynkami na śmierć i życie, lecz nade wszystko były publiczną areną rywalizacji o męski prymat. Sportowe zmagania, mające na celu szybszą adaptację chłopców do srogich reguł męskiego świata, opartych na kulcie siły i imperatywie zemsty, przemieniały się nierzadko w pole bitwy oraz stawały się zarzewiem konfliktów, co dobrze obrazują dwa epizody Sagi o Egilu. Pierwszy z nich traktuje o zawodach piłkarskich, podczas których ledwie siedmioletni Egil, doznawszy porażki i upokorzenia w rywalizacji ze starszym przeciwnikiem, mści się, zabijając swojego rywala,

jest taka, że słońce nigdy nie może świecić na jego głowicę i że nie wolno go obnażyć w obecności kobiety. Rana zadana tym mieczem nie zagoi się, jeżeli się nie przyłoży do niej kamienia zdrowia, który należy do miecza" (L 141).

39 Saga ta zajmuje wyjątkowe miejsce na mapie literatury staroislandzkiej, gdyż pierwszoplanowe role odgrywają $\mathrm{w}$ niej silne, niezależne i charyzmatyczne postaci kobiece, z Gudrun na czele, odważnie występujące przeciw męskiej dominacji. Niektórzy badacze, mając na uwadze feminocentryzm sagi, twierdzili nawet, że jej autorem była kobieta. Taką hipotezę stawia m.in. L. Auerbach, Female Experience and Authorial Intention in Laxdoela saga, "Saga-Book of the Viking Society” 25 (1998-2001), s. 45-46.

40 Temat ten rozwijają: M.W. Williams, Social Scandinavia...; J.D. Martin, "Svá lýkr hér hverju hestaðingi”. Sports and Games in Icelandic Saga Literature, „Scandinavian Studies" 1 (2003); R. Gogosz, Horse-fights. The Brutal Entertainment of the Icelanders in the Middle Ages, „Sredniowiecze Polskie i Powszechne” 5 (2013). 
czym wywołuje niezadowolenie ojca oraz waśnie $\mathrm{w}$ regionie (vide E 78-79). Drugi epizod dotyczy zaś konfrontacji dwunastoletniego Egila ze swoim ojcem, Skalla-Grimem, która tylko dzięki interwencji jednej z kobiet nie kończy się synobójstwem:

Thord i Egil byli w tej grze [w zawodach piłkarskich - R.J.] przeciwnikami Skalla-Grima, zmęczyli go i zyskali nad nim przewagę. Wieczorem jednak, po zachodzie słońca, zaczęło się Egilowi i Thordowi wieść gorzej, Grim stał się tak mocny, że chwycił Thorda w pół i uniósł w górę, potem rzucił nim o ziemię z taką siłą, że połamał mu wszystkie kości, chłopak wyzionął ducha na miejscu. Potem złapał Egila. [...] Brak zawołała: „przemieniło cię w berserka, Skalla-Grimie! Na własnego syna szał swój kierujesz!” (E 79).

Wolno przypuszczać, że agresja Skalla-Grima wobec syna, wywołana urażeniem jego męskiej dumy na oczach innych mężczyzn przez krótkotrwałe uzyskanie przewagi fizycznej, ma swe źródło w obawie ojca przed potencjalną zamianą ról na płaszczyźnie rodzinnej oraz społecznej. Ów strach był prawdopodobnie tym większy, że wielu (a zwłaszcza jego matka) widziało w niesfornym Egilu, który dysponował nadzwyczajną jak na swój wiek siłą, przyszłego przywódcę („przeznaczone jest mu być wodzem”; E 79). Zapewne niepokój Skalla-Grima budził również fakt, że Egil był wówczas w wieku, w którym chłopcy zaczynali już brać aktywny udział w życiu społecznym $^{41}$. Stąd o ile pierwszy postępek swego syna Skalla-Grim jeszcze zbagatelizował i potraktował jako znak ostrzegawczy („był bardzo niezadowolony z tego, co zaszło", lecz nie wyciągnął żadnych konsekwencji wobec syna; E 79), o tyle późniejszy jego czyn uznał już za otwarty bunt przeciw swojemu autorytetowi tak ojcowskie$\mathrm{mu}$, jak społecznemu ${ }^{42}$. Nazbyt agresywną reakcję Skalla-Grima, wywołaną atakiem syna na jego męską tożsamość, można więc w tym

${ }_{41}$ Zob. C. Callow, Transitions to Adulthood in Early Icelandic Society, w: Children, Childhood and Society, ed. by S. Crawford, G. Shepherd, Oxford 2007, s. 54.

${ }_{42}$ Zob. Á. Jakobsson, Troublesome Children in the Sagas of Icelanders, „Saga-Book of the Viking Society" 27 (2003), s. 14. Badacz ten omawia szczegółowiej skomplikowane relacje między Egilem a Skalla-Grimem w szkicu Egils saga and 
świetle odczytywać jako próbę stłumienia, czy wręcz unicestwienia, zagrożenia płynącego ze strony dorastającego do roli mężczyzny Egila. Próbę skądinąd skuteczną, gdyż skruszony Egil decyduje się po tym wydarzeniu na wyjazd zagraniczny, a więc poniekąd rozpoczyna inicjację na nowo ${ }^{43}$.

\section{Kodeks honorowy}

Wedle treściwej definicji zawartej w jednej z sag, człowiek honoru to jednostka, której „reputacji i prestiżu nie splamiła żadna hańba” (VG 20). Staroislandzkie pojęcie honoru można zatem sprowadzić, za Meulengrachtem Sørensenem, do normy społecznej, systemu niepisanych zasad, które mężczyzna winien respektować, by nie okryć się niesławą ${ }^{44}$. Naczelnym zadaniem każdego przedstawiciela płci męskiej był, jak już powiedziano, krwawy odwet za zniewagę lub splamienie dobrego imienia rodu, a uchylanie się od tego obowiązku ściągało na mężczyznę hańbę. Istotną rolę odgrywały w tym względzie kobiety, które dodatkowo podburzały mężczyzn, stanowczo domagając się od nich natychmiastowej reakcji w postaci czynu zbrojnego ${ }^{45}$. Motywacyjne, jeśli tak rzec, przemówienia kobiet były nad wyraz ostre w swej wymowie i uderzały w dumę zwlekającego z zemstą mężczyzny. Oto jeden z przykładów, mowa Thorgerd

Empathy. Emotions and Moral Issues in a Dysfunctional Saga Family, „Scandinavian Studies" 1 (2008).

${ }_{43}$ Niektórzy interpretatorzy Sagi o Egilu twierdzą, że tytułowy bohater nigdy nie osiągnął, ze względu na społecznie niedopasowanie, pełnej dojrzałości (Á. Jakobsson, Troublesome..., s. 16).

${ }_{44}$ Zob. P. Meulengracht Sørensen, Fortoelling og are. Studier i isloendingesagaerne, Århus 1993, s. 187.

45 Zob. na ten temat: E. Mundal, The Position of Women in Old Norse Society and the Basis for their Power, „NORA. Nordic Journal of Feminist and Gender Research" 1 (1994); C.J. Clover, Hildigunnr's Lament, w: Cold Counsel... 
wzywającej synów do odwetu na Bollim: „Straszne to jest nieszczęście mieć synów niezdolnych do czynu. Jestem przekonana, że byłoby lepiej, gdybyście byli córkami waszego ojca, które by się powydawało za mąż” (L 133). Jak można się domyślać, reakcją na takie dictum, zasadzające się na urągającym porównaniu do kobiet, był niemal natychmiastowy odwet na sprawcy zabójstwa członka rodziny. Nic więc dziwnego, że wobec tak silnie wywieranej na ówczesnych mężczyznach presji związanej z zemstą, wielu z nich, z różnych powodów nie będąc w stanie jej dokonać, wolało raczej umrzeć aniżeli żyć w hańbie (przykładem tytułowy bohater Sagi o Njalu; zob. N 261).

Równie niehonorowa była odmowa udziału w pojedynku. Otóż w średniowiecznej Islandii istniały dwa rodzaje pojedynków: einvígi, czyli rzadziej praktykowana walka bez określonych reguł, w której uczestniczyli jedynie pojedynkujący się rywale, a także hólmganga (dosł. „pójście na wyspę”) - uznana przez prawo walka, odbywająca się w miejscu oddalonym, najczęściej na małej wyspie lub na specjalnie przygotowanym do tego wydarzenia "boisku holmowym” (E 152). Ten rodzaj pojedynku odbywał się według ściśle ustalonych reguł, które przed walką odczytywano uczestnikom. Walczącym, zaopatrzonym w miecz i trzy tarcze, towarzyszyli sekundanci, a pierwsze uderzenie wyprowadzał mężczyzna, którego wyzwano na pojedynek $^{46}$. Walkę toczono do momentu, w którym jeden z rywali został zabity lub nie mógł kontynuować pojedynku $\mathrm{z}$ racji odniesionych ran, zaś nagrodą za triumf było legalne zajęcie majątku pokonanego $^{47}$. Taki sposób załatwiania zatargów został na Islandii zakazany w $1006 \mathrm{roku}^{48}$, a wpłynął na to nierozstrzygnięty pojedynek dwóch skaldów, Gunnlauga i Hrafna, które to zdarzenie lakonicznie relacjonuje autor Sagi o Gunnlaugu Wężowym Języku (Gunnlaugs saga orm-

46 Zob. G. Jones, Some Characteristics of the Icelandic 'Hólmganga', „The Journal of English and Germanic Philology” 2 (1933), s. 214-215.

47 Zob. M. Ciklamini, The Old Icelandic Duel, „Scandinavian Studies” 3 (1963), s. 176. Wyzwanie na pojedynek było więc nie tylko „zamachem” na męskość rywala, lecz także na jego status społeczny.

48 Zob. K. Hastrup, Culture and History..., s. 214. 
stungu), pisząc, że decyzję podjęto „na wniosek najrozumniejszych mężów zgromadzonych na sejmie” (G 56). Wiele świadectw sagowych (m.in. N 41; HT 32; VG 53) potwierdza, że odmowę stoczenia pojedynku (a także ucieczkę z pola bitwy) poczytywano wówczas za tchórzostwo, a jej bezpośrednim następstwem były utrata honoru i społeczne napiętnowanie ${ }^{49}$. Mężczyznę, który się tego dopuścił, nazywano pejoratywnie níðingr (dosł. „łajdak”, „łotr”), a wyraz ten był jedną z najbardziej obraźliwych obelg i odnosił się do utraty męskich cech charakteru ${ }^{50}$. Jak widać, pojęcie honoru, oparte na fundamencie chorobliwego heroizmu, było w średniowiecznej Islandii podszyte strachem przed wyłączeniem $\mathrm{z}$ grona ortodoksyjnych mężczyzn ${ }^{51}$ oraz lękiem przed utratą społecznego uznania i posądzeniem o niemęskość.

Jeśli pojedynek był najbardziej honorowym sposobem na rozwiązanie zatargu między mężczyznami („tak będzie po męsku”, poucza młodszych braci najstarszy syn Njala; N 104), to grupowy atak na osamotnionego rywala uwłaczał honorowi napastników, o czym przypomina jeden z protagonistów Sagi o Viga-Glumie: „Nie jest bowiem odważnym czynem, gdy trzech staje przeciwko jednemu" (VG 62). Co zaskakujące, zabicie bezbronnego lub kapitulującego rywala nie zawsze było, wnosząc $\mathrm{z}$ analizowanego korpusu tekstów, wartościowane jako jednoznacznie negatywne, by przytoczyć dwie najmocniej zapadające $\mathrm{w}$ pamięć sceny: podstępne, nieszlachetne

49 Wyjątek stanowi pojedynek Hallfreda z Grisem, opisany w dziesiątym rozdziale Sagi o Hallfredzie (Hallfreðar saga vandroeðaskálds). Ten pierwszy wycofał się z walki na wieść o śmierci króla Olafa Tryggvasona, z którym pozostawał w serdecznych relacjach, a wcześniej terminował na jego dworze. Decyzja Hallfreda początkowo nie spotkała się ze zrozumieniem przeciwnego obozu, który orzekł, że „skald zachowuje się niemęsko" (H 141), jednak ostatecznie - po interwencji samego Grisa - nie została uznana za tchórzostwo.

50 Zob. P. Meulengracht Sørensen, The Unmanly Man...

51 Nawiązuję tu do terminu „męskość ortodoksyjna” (orthodox masculinity), którym E. Anderson (Inclusive Masculinity..., s. 96) określa „hegemoniczną formę konserwatywnej męskości” („hegemonic form of conservative masculinity”). 
zranienie Gunnlauga przez Hrafna podczas ich drugiego pojedynku (G 64) ${ }^{52}$ i ścięcie zrezygnowanego Kjartana przez Bolliego (L 126). Wprawdzie oba czyny pociągają za sobą zemstę rodową, lecz ich ocena nie jest tak surowa, jak w przypadku odmowy udziału w pojedynku i grupowej napaści na jednego rywala. Odmiennie rzecz ma się $\mathrm{z}$ kolei $\mathrm{z}$ podpaleniem wroga $\mathrm{w}$ jego domostwie; zarówno podłożenie ognia przez Thoriego pod gospodarstwo Blund-Ketila (Saga o Hønsa-Thórim [Honsa-Póris saga]), jak i podpalenie dworu Njala przez Flosiego są zgodnie określane jako czyny haniebne (HT 25; N 264), a sprawcy zostają pogardliwie nazwani chłopcami (N 260), czyli symbolicznie pozbawieni statusu mężczyzny. Skądinąd sam Flosi ma świadomość, że swoim czynem ściągnął na siebie hańbę, i konstatuje samokrytycznie: „Nie szczyćmy się tym, że Njal został spalony, bo tym sławy sobie nie zyskaliśmy” (N 265).

\section{Przemoc wobec kobiet}

Jak pisze Joseph H. Pleck, patriarchat to dualny system, w którym mężczyźni dążą do sprawowania władzy nad kobietami i innymi mężczyznami ${ }^{53}$. Jednym $z$ narzędzi służących do ustanowienia i podtrzymania patriarchatu, a w rezultacie do uzyskania kontroli i dominacji, jest przemoc ${ }^{54}$. W patriarchalnym społeczeństwie is-

52 Theodore M. Andersson (The Displacement of the Heroic Ideal in the Family Sagas, „Speculum” 45 (1970), no. 4, s. 579) nazwał tę scenę „najbardziej niehonorowym epizodem w literaturze sagowej" ("the most dishonorable episode in saga literature").

53 Zob. J.H. Pleck, Men's Power with Women, Other Men, and Society. A Men's Movement Analysis, w: The Gender Gap in Psychotherapy. Social Realities and Psychological Processes, ed. by E.H. Carmen, P.P. Rieker, New York 1984, s. 86.

54 Zob. M. Kaufman, The Construction of Masculinity and the Triad of Men's Violence, w: Beyond Patriarchy. Essays by Men on Pleasure, Power, and Change, ed. by M. Kaufman, Toronto 1987. 
landzkim doby średniowiecza kobiety były pasywne i podporządkowane mężczyznom, o czym świadczy nie tylko niemal całkowite wykluczenie ich ze sfery publicznej ${ }^{55}$ i z gier o honor ${ }^{56}$, lecz także pozbawienie prawa do samostanowienia w kwestii zawierania małżeństw ${ }^{57}$. Niemniej stosowanie przemocy wobec kobiet uznawano na ogół za postępowanie niegodne mężczyzny, czego dowodem jeden $\mathrm{z}$ epizodów Sagi o mieszkańcach Eyri (Eyrbyggja saga). Oto podczas walki jeden z mężczyzn obciął dłoń Aud, ta jednak za wszelką cenę usiłuje zataić ten fakt, by uchronić męża, pomawianego o ten czyn, przed piętnem człowieka bez honoru. Thorarinn został ostatecznie oczyszczony z niesłusznych podejrzeń, zaś rzeczywistego sprawcę, Odda, powieszono ${ }^{58}$. Mimo że w średniowiecznej Islandii potępiano wszelkie akty męskiej agresji wobec kobiet, z tego też względu celem zemsty rodowej byli wyłącznie mężczyźni, to jednak ówczesne prawo zezwalało w wyjątkowych przypadkach na zabicie kobiety przez mężczyznę, na przykład za uprawianie czarów ${ }^{59}$. Co osobliwe, $\mathrm{w}$ wielu sagach rodowych można doszukać się przykładów instrumentalnego traktowania kobiet przez mężczyzn, a także przypadków agresji werbalnej, fizycznej i seksualnej. Toteż można założyć, że męska przemoc wobec kobiet nie była w średniowiecznej Islandii zjawiskiem incydentalnym.

Jedną z najciężej znieważanych postaci kobiecych w sagach rodowych - chociaż ona sama nie pozostaje w tej materii dłużna - jest

55 Rozwodzi się na ten temat Z. Borovsky, Never in Public. Women and Performance in Old Norse Literature, „The Journal of American Folklore” 443 (1999).

56 Określenie P. Bourdieu (Męska dominacja, przeł. L. Kopciewicz, Warszawa 2004, s. 63).

57 Zob. J. Jochens, Women in Old Norse Society, Ithaca-London 1995, s. 25, 27.

58 Zob. Eyrbyggja saga, E.Ó. Sveinsson, M. Pórðarson gáfu út, Reykjavík 1935 (ÍF IV) - rozdział 18 i 20; zob. też Á. Egilsdóttir, Masculinity and/or Peace?...

59 Zob. W.I. Miller, Beating Up on Women and Old Men and Other Enormities. A Social Historical Inquiry into Literary Sources, „Mercer Law Review” 3 (1988), s. 765. 
Hallgerda (Saga o Njalu), nazwana przez Skarphedina „kurwą"60, „tą, co kąty sobą wyciera” (N 190) oraz siarczyście spoliczkowana przez swojego męża Gunnara za kradzież żywności (N 110) ${ }^{61}$. O ile Hallgerda mści się na mężu, odmawiając mu pomocy, gdy zostaje on otoczony przez wrogów i ostatecznie zabity (N 161), o tyle Gudrun (Saga rodu $z$ Laxdalu), uderzona w twarz przez małżonka za domaganie się coraz to droższych podarunków (L 75), niemal natychmiast decyduje się na rozwód ${ }^{62}$, przy okazji dyskredytując jego męskość poprzez wręczenie mu niemęskiej koszuli z głębokim wycięciem. Wypada w tym kontekście napomknąć, że noszenie przez mężczyzn kobiecych ubrań było w średniowiecznej Islandii wzbronione. Wedle ówczesnego prawa taki czyn podlegał karze czasowej banicji ${ }^{63}$. Podarunek Gudrun, godzący w honor męża, można zatem uznać za symbol wykluczenia z męskiej społeczności.

Zdarza się nadto, że w przypływie gniewu lub w obronie swojej męskiej tożsamości mężczyźni posuwają się do zabicia kobiety (jak Skalla-Grim; E 80) oraz gwałtu, co ilustruje Saga o Grettirze (rozdz. 75). Bezlitośnie wykpiony przez jedną z kobiet za niewspółmierny do ogromnej postury rozmiar członka, Grettir w rewanżu dopuszcza się gwałtu, o czym autor sagi informuje implicite (zob. GR 239-241). Przemoc seksualna jest dla protagonisty środkiem dyscyplinującym, mającym przyprowadzić krnąbrną kobietę do

60 Użycie tego wyrazu (isl. púta) jest niecodzienne. W średniowiecznej Islandii kobiety nie uprawiały bowiem prostytucji, a samo społeczeństwo było dość liberalne w kwestii kobiecej seksualności (L. Lönnroth, Njáls saga. A Critical Introduction, Berkeley 1976, s. 116).

${ }^{61}$ Kradzież mienia była jednym z najpoważniejszych przestępstw. Ówczesne prawo wyróżniało dwa rodzaje kradzieży: jawną (rán) oraz skrytą (pióf). Pierwszy wiązał się z publicznym obwieszczeniem kradzieży przez złodzieja, zaś drugi z ukrywaniem przez sprawcę swojego czynu. Surowszej karze podlegała kradzież skryta.

62 Jak zauważa Jenny Jochens (Women in Old Norse..., s. 58), męska przemoc wobec kobiet jest w sagach najczęstszą przyczyną rozwodów.

${ }^{63}$ Zob. Laws of Early Iceland. Grágás, vol. 2, transl. by A. Dennis, P. Foote, R. Perkins, Winnipeg 2000, s. 219. 
porządku ${ }^{64}$, narzędziem służącym do przywrócenia obowiązującej acz chwilowo zachwianej - hierarchii płciowej. Zjadliwą drwinę $\mathrm{z}$ rozmiaru jego członka można w tym kontekście uznać nie tylko za jawny, bezpardonowy atak na męskość, lecz także poniekąd w szerszej perspektywie - za symboliczną próbę zdyskredytowania patriarchalnego porządku. Gwałt stanowi natomiast oręż, stąd porównanie penisa do miecza i „wojownicza” leksyka triumfalnego wiersza Grettira (GR 240-241), w walce o zachowanie społecznego status quo i podtrzymanie władzy nad kobietami ${ }^{65}$. Gwałt jest zarazem najbardziej ekstremalną formą potwierdzenia męskości, swoistą manifestacją męskiej siły i potencji.

\section{Okazywanie emocji}

Jak nietrudno zauważyć, wygląd, zachowanie i czyny mężczyzn poddawano w średniowiecznej Islandii permanentnej, częstokroć nazbyt surowej, ocenie. Od mężczyzny wymagano, by w każdej sytuacji odznaczał się męską postawą i zachowywał mężnie, a dotyczyło to także kwestii okazywania emocji. Mężczyzna nie tylko winien był cechować się heroizmem, odwagą i siłą fizyczną, ale także musiał być powściągliwy, zdystansowany i nieskłonny do objawiania swoich uczuć, albowiem (nadmierna) emocjonalność była domeną kobiet. Jak można się domyślać, pohamowanie emocji było dla ówczesnych mężczyzn niełatwym zadaniem, biorąc pod uwagę częste testy męskości i liczne próby kwestionowania ich męskiej tożsamości. Presja była tym większa, że emocje, takie jak upokorzenie, wstyd, strach,

64 Zob. F. Charpentier Ljungqvist, Rape in the Icelandic Sagas. An Insight in the Perceptions about Sexual Assaults on Women in the Old Norse World, "Journal of Family History" 4 (2015), s. 435.

${ }^{65}$ Co ciekawe, we wcześniejszym epizodzie sagi (rozdz. 19) Grettir skutecznie broni jedną z kobiet przed zbiorowym gwałtem planowanym przez berserków, zyskując tym sławę mężnego człowieka (GR 69). 
objawiające się zmianami somatycznymi ${ }^{66}$ (np. zaczerwienieniem lub nerwowymi spazmami), zdradzają, jak argumentuje Pierre Bourdieu, „mimowolną podległość ciała próbującego się bronić przed osądem (oceną) ze strony grup dominujących" ${ }^{67}$. Słowem, sprowokowanie mężczyzny do okazania słabości, poprzez wywołanie niekontrolowanej, wyrażonej przez jego ciało, reakcji emocjonalnej, wiązało się z ustanowieniem relacji podległości, rozdziału na dominujących i zdominowanych.

Za przykład niech posłuży epizod przywołanej już parokrotnie Sagi o Njalu, obrazujący skrajne reakcje trzech synów tytułowego bohatera - Skarphedina, Grima i Helgiego - na dotkliwą zniewagę ich męskości, której dopuścił się Sigmund, układając obelżywy wiersz. Jak głosi saga, najstarszemu „na czoło wystąpił [...] pot kroplisty, a na policzkach ukazały się czerwone plamy, a to się nigdy wcześniej nie zdarzało. Grim milczał, przygryzając wargi. Helgi ani drgnął" (N 103). Można mniemać, że tylko Helgi, a w mniejszym stopniu również Grim, zaprezentowali w tej sytuacji prawdziwie męską postawę, nie dając się wyprowadzić z równowagi oraz ignorując prześmiewcze wystąpienie Sigmunda. Zaskakuje natomiast postawa Skarphedina, kreowanego przez twórcę sagi na wzorzec męskości (był „mocny i męski”; N 240), który zwykle był „spokojny i opanowany” oraz miał „bladą twarz”, co w kulturze islandzkiej stanowiło znak opanowania (N 69). Jednostkowy brak samokontroli Skarphedina stawia go chwilowo, z czego on sam zdaje sobie zresztą sprawę, w pozycji podległości wobec Sigmunda, dotychczasowa hierarchia mężczyzn zostaje wszakże szybko przywrócona za sprawą brutalnej zemsty (N 105) ${ }^{68}$.

66 Zob. w tej sprawie: K. Wolf, Somatic Semiotics. Emotions and the Human Face in the Sagas and poettir of Icelanders, "Traditio” 69 (2014); E. Porter, T. Manrique Antón, Flushing in Anger, Blushing in Shame. Somatic Markers in Old Norse Emotional Expressions, „Cognitive Linguistic Studies” 2 (2015), no. 1.

${ }^{67}$ P. Bourdieu, Męska dominacja..., s. 51.

68 Skarphedin obcina Sigmundowi głowę, a jego czyn można interpretować zarówno jako próbę efektownego, by tak rzec, zamanifestowania triumfu nad ry- 
Co więcej, okazywania emocji należało wystrzegać się nawet po śmierci bliskich, bowiem, jak oschle instruuje Kari, „co innego przystoi mężowi niż ronienie łez nad umarłymi” (N 267) ${ }^{69}$. Co oczywiste, wielu sagowych protagonistów, mając na uwadze ową przestrogę, za wszelką cenę usiłuje powstrzymać się od płaczu po utracie najbliższych, uciekając się do rozmaitych sposobów ${ }^{70}$. Przykładowo po śmierci synów Egil przez trzy dni stroni od ludzi, tak mocno tłumiąc w sobie płacz, że jego ciało nabrzmiało, a "kaftan i spodnie pękły” (E 186). Ostatecznie jego ból koi ułożenie elegijnego wiersza na ich cześć (E 188), który pełni funkcję zastępczego środka uzewnętrznienia uczuć. Znacznie radykalniejszym lekarstwem na cierpienie po stracie członków rodziny jest odwet na tych, którzy przyczynili się do ich śmierci. Jak radzi Skalla-Grim pogrążonemu w żałobie ojcu, „należy raczej szukać zemsty” aniżeli „oddawać się smutkowi [...], bezwładnie kładąc się do łoża" (E 47). Zdaje się przy tym, że emocjonalne reakcje mężczyzn na wieść o śmierci najbliższych były niekiedy społecznie usprawiedliwiane i nie zawsze godziły w męski honor $^{71}$. Świadczyć mogą o tym, na przykład, wyrozumiałość społeczności dla niemęskiego (zob. N 271), jak sam je określił, zacho-

walem, jak i formę kary za obraźliwy wiersz. W tym duchu można również odczytywać ścięcie Björna przez Thorda, opisane w Sadze o Björnie (Bjarnar saga Hitdoelakappa). Zob. Bjarnar saga Hítdoelakappa, S. Nordal, G. Jónsson gáfu út, Reykjavík 1938 (ÍF III), rozdział 32.

${ }_{69}$ Jak zauważa jedna z badaczek, w sagach o wiele częściej rozpaczają ojcowie po stracie synów niż odwrotnie. Wyjątek stanowią przybrani synowie, którzy rzadko kryją się z żalem po śmierci swoich opiekunów (C. Jorgensen Itnyre, The Emotional Universe of Medieval Icelandic Fathers and Sons, w: Medieval Family Roles. A Book of Essays, ed. by C. Jorgensen Itnyre, New York 1996, s. 184).

70 Warto na marginesie nadmienić, że motyw płaczu mężczyzn często pojawia się również w mitologii staronordyckiej oraz w sagach królewskich. Zagadnienie to podnoszą: E.M. Goeres, How to Do Things with Tears. The Funeral of Magnús inn góði, „Saga-Book of the Viking Society” 37 (2013); K. Mills, Grief, Gender, and Genre. Male Weeping in Snorri's Account of Baldr's Death, Kings' Sagas, and Gesta Danorum, „The Journal of English and Germanic Philology” 4 (2014).

71 Taką tezę stawia K. Wolf, Somatic Semiotics..., s. 139. 
wania Thorhalla po śmierci Njala i deklaracja, że „nie powinien poczytywać sobie tego za hańbę" (N 272). Nie zmienia to jednak faktu, że bohaterowie sag rodowych częstokroć posądzają antagonistów o płacz, aby podważyć w ten sposób ich męskość (spotyka to chociażby Gunnara i Skarphedina; por. N 120-121, 264, 341), a konsekwencją tego rodzaju złośliwych insynuacji jest najczęściej zemsta znieważonego mężczyzny.

\section{Dominacja i podległość}

Według Connell, dominacja jednej grupy mężczyzn wiąże się zawsze z marginalizacją (marginalization) i/lub podporządkowaniem (subordination) innych męskości ${ }^{72}$. Męskości zmarginalizowane nie wykazują pewnych cech typowych dla męskości hegemonicznej (np. nie stosują przemocy), lecz przyzwalają na patriarchalny porządek i są jego beneficjentami. Męskości podporządkowane podlegają zaś symbolicznemu wykluczeniu za przejawianie cech i zachowań niezgodnych $\mathrm{z}$ modelowym wzorcem mężczyzny. Rozpoznania te można odnieść, zdając sobie sprawę z ryzyka anachronizmu, do opisu relacji między mężczyznami w średniowiecznej Islandii oraz ich walki o władzę. Warto w tym celu ukazać trzy typy sagowych męskości: Hruta, będącego uosobieniem męskości hegemonicznej, Thorda, reprezentującego męskość podporządkowaną, oraz Njala, ucieleśniającego męskość zmarginalizowaną.

Jak precyzuje Saga rodu z Laxdalu, Hrut jest „męski” (L 14), dzięki sile fizycznej zdobywał „zawsze pierwsze miejsce we wszelkich próbach sił męskich” (L 36), jest również „najlepszym rębaczem” (L 37), nie unika walki mimo przewagi liczebnej przeciwnika i nie waha się powziąć odwetu za zabicie syna (L 86). Ponadto jest on niezależny i rozumny (L 38), potrafi kontrolować emocje (L 87), cieszy się po-

72 R. Connell, Masculinities, s. 78, 80. 
ważaniem społeczności („lud go sławił”; L 85), „ma władzę” (L 89), a jego ród jest „prawie nietykalny” (L 57). Do tego stanu rzeczy przyczynia się niewątpliwie posiadanie szesnastu synów, gdyż taka liczba męskich potomków dawała w średniowiecznej Islandii „sławę i potęgę" (L 39). Dzięki swoim cechom Hrut szybko pnie się w hierarchii społecznej ${ }^{73}$, stale pomnażając majątek i poszerzając swoje wpływy w regionie, nawet kosztem brata Höskulda, nad którym także zdobywa przewagę. Słowem, męskość daje władzę, a jak nietrudno spostrzec, Hrut skupia w sobie wszystkie cechy modelowego mężczyzny, pożądane przez ówczesne społeczeństwo: siłę, heroizm, mądrość, autonomię, opanowanie, żądzę zemsty i potencję, która w średniowieczu była jednym z głównych wyznaczników męskości ${ }^{74}$.

Na przeciwległym biegunie drabiny społecznej przedstawionej w owej sadze znajduje się natomiast Thord, zdominowany nie tylko przez innych mężczyzn, ale i przez swoją żonę Vigdis, która twardą ręką „sprawuje rządy” (L 25) na niwie rodzinnej i społecznej. O ile Hruta można uznać za wcielenie staroislandzkiej męskości, o tyle Thord jest jej zaprzeczeniem. Będąc człowiekiem bojaźliwym (L 30), bezdzietnym (L 31), uległym wobec żony i niezdolnym do heroicznego zrywu, Thord staje się jednostką „mało znaczącą” (L 31), pogardzaną przez innych mężczyzn, którzy odsuwają go od sprawowania rządów nad regionem, a wszelkie "męskie” sprawy konsultują $\mathrm{z}$ jego żoną ${ }^{75}$. Z ust jednego $\mathrm{z}$ nich pada nawet stwierdzenie, że Vigdis „podle wyszła za mąż” (L 29), saga głosi nadto, że ich małżeństwo zostało zawarte „bardziej ze względu na majątek niż na poparcie, jakie mógł jej dać małżonek" (L 17). Niemożność przystosowania się do

73 Zob. V. Árnason, Morality and Social Structure in the Icelandic Sagas, „The Journal of English and Germanic Philology" 2 (1991).

74 Zob. V.L. Bullough, On Being a Male in the Middle Ages, w: Medieval Masculinities. Regarding Men in the Middle Ages, ed. by C.A. Lees, Minneapolis 1994, s. 41. Nawiasem mówiąc, w nieco innym świetle kwestię potencji Hruta przedstawia Saga o Njalu (por. rozdz. 7).

75 Na temat „męskich” kobiet w tejże sadze pisze szerzej L. Auerbach, Female Experience... 
reguł agresywnej męskości wiązała się zatem z utratą pozycji, władzy, a nawet ze społecznym odtrąceniem, co raz jeszcze uzmysławia, jak wygórowane wymagania stawiano ówczesnym mężczyznom ${ }^{76}$.

Z kolei Njala można by ulokować pomiędzy mężczyznami hegemonicznymi a podporządkowanymi. Protagonista nigdy nie używa swojego miecza, polegając tyleż na sile fizycznej, ile na sile argumentów, co automatycznie dyskwalifikuje go w oczach dominujących mężczyzn, przemocą torujących sobie drogę do podporządkowania innych męskości. Njal ma ponadto znaczący defekt fizyczny, mianowicie nie ma zarostu (N 84), uchodzącego wówczas za jedną z głównych oznak męskości ${ }^{77}$. Z powodu swojej odmienności jest on bezlitośnie wykpiwany (określa się go „dziadem bezbrodym”; N 102) i zajmuje marginalną pozycję w męskiej hierarchii ${ }^{78}$. Jest zarazem znakomitym znawcą prawa, czynnie uczestniczy w rozstrzyganiu prawnych sporów, dzięki czemu niejako rekompensuje swój „niemęski” wygląd i zyskuje poważanie społeczności. Mimo że protagonista nie został zakwalifikowany do grupy hegemonicznych mężczyzn i rozmyślnie godzi się z takim stanem rzeczy, to milcząco akceptuje surowe zasady panujące $\mathrm{w}$ męskim świecie, czego świadectwem jest chociażby gest przyzwolenia na odwet synów na Sigmundzie (zob. N 103-104). Symboliczna zgoda Njala na planowaną zemstę, objawiająca się brakiem stanowczej reakcji, która mogłaby powstrzymać zapędy synów i udaremnić ich zamiar, stawia protagonistę w roli współuczestnika, a być może nawet współwinowajcy ${ }^{79}$. Taką interpretację uprawomoc-

76 Niektórzy bohaterowie sag rodowych tak bardzo pragną dowieść swojej męskości i odwagi, że niekiedy narażają się swoimi działaniami na śmieszność. W krzywym zwierciadle ukazał to zagadnienie autor Sagi o Njalu (por. rozdz. 150-152), poddając krytyce rygorystyczne reguły męskiego świata. Czyni to na przykładzie tchórzliwego i wyśmiewanego nawet przez swoją żonę Björna, który odgrywa rolę bohaterskiego mężczyzny, walcząc u boku Kariego. Epizod ten komentuje W.E. Judd, Valgerðr's Smile, „Scandinavian Studies” 3 (1984).

77 Zob. Á. Jakobsson, Masculinity..., s. 196.

78 Zob. C. Phelpstead, Hair Today..., s. 10.

79 Taką wykładnię sugeruje M. Stieblin-Kamienski, Ze świata sag, przeł. J. Litwiniuk, Warszawa 1982, s. 125. 
nia pochwalna, aczkolwiek przesycona ironią, eksklamacja („błogosławione wasze ręce! Teraz nie będzie już sądu polubownego"; N 105), wyartykułowana przezeń tuż po ogłoszeniu zabójstwa ${ }^{80}$ Sigmunda i jego kompanów przez Skarphedina, Grima i Helgiego. Jego współwinę łagodzi jednakże fakt, że ówczesne prawo dozwalało na zabicie osoby, która dopuściła się, jak Sigmund, komponowania i publicznego prezentowania „potwarczych rymów” (N 106), podważających męskość antagonisty ${ }^{81}$. Za okoliczność łagodzącą można też uznać jego wcześniejsze próby mediacji, mające na celu skłonienie synów do ugody (zob. N 100-101). Toteż Njal uczestniczy w owym brutalnym męskim świecie jedynie pośrednio, na zasadzie przyzwolenia. Mając świadomość niemożności złagodzenia jego nieprzejednanych reguł, protagonista je akceptuje, lecz jednocześnie odgrywa rolę rozjemcy, za wszelką cenę dążącego do zapobieżenia krwawemu finałowi zatargu. Przypadek Njala pokazuje, że nawet pokojowo usposobiony i „niemęsko” wyglądający mężczyzna może się w tym świecie z powodzeniem odnaleźć, a kluczem do sukcesu jest znalezienie kompromisu między wymogami agresywnej męskości a dążeniem do pojednania zwaśnionych stron i bezkrwawego zażegnania konfliktu.

\section{Podsumowanie}

Selektywna z konieczności analiza, tak pod względem doboru tekstów, jak omawianych zagadnień, podjęta w niniejszym szkicu zaświadcza o niebywale rygorystycznych i nieuznających kompromisu wymogach stawianych mężczyznom przez średniowieczne społe-

80 Średniowieczni Islandczycy stosowali rozróżnienie na zabójstwo (víg) i morderstwo (morð). Pierwszy czyn, obwieszczany przez sprawcę tuż po jego dokonaniu, mógł być zrekompensowany odszkodowaniem. Morderstwo, trzymane przez sprawcę w sekrecie, wykluczało taką możliwość, okrywało go hańbą i skazywało na banicję (J. Byock, Viking Age Iceland, London 2001, s. 225-226).

81 Zob. Laws of Early Iceland..., s. 354. 
czeństwo islandzkie, w którym pojęcia takie jak honor i dyshonor odgrywały kluczową rolę. Niepisany system nakazów i zakazów, mający ocalić mężczyzn przed hańbą, napiętnowaniem i utratą pozycji społecznej, opresyjnie oddziaływał na nich samych. Z ekskluzywnego grona „prawdziwych” mężczyzn wykluczało przecież nie tylko sprzeniewierzenie się ideałom agresywnej męskości, ale nawet nazbyt wrażliwe usposobienie. Owe nieformalne zasady, klarownie wyznaczające podział na dominujących i zdominowanych, honorowych i niehonorowych, męskich i niemęskich, składały się na represyjny system oparty na zbrojnym rozwiązywaniu zatargów. Trzeba przy tym podkreślić, że tak wymodelowany przez twórców sag męski modus operandi, nierzadko rozmyślnie przejaskrawiony w celach ludycznych, był wyrazem ich krytycznego stosunku do, mocno zakorzenionego w świadomości społecznej, mitu męskości.

\section{Bibliografia}

\section{Źródła}

Bjarnar saga Hítdoelakappa, S. Nordal, G. Jónsson gáfu út, Reykjavík 1938 (ÍF III). Eyrbyggja saga, E.Ó. Sveinsson, M. Pórðarson gáfu út, Reykjavík 1935 (ÍF IV).

Grettis saga Ásmundarsonar, G. Jónsson gaf út, Reykjavík 1936 (ÍF VII).

Saga o Egilu, przeł. A. Załuska-Strömberg, Poznań 1974.

Saga o Gunnlaugu Wężowym Języku, przeł. A. Załuska-Strömberg, Wrocław 1968. Saga o Hallfredzie skaldzie kłopotliwym, wstęp i przeł. J. Morawiec, Wrocław 2011. Saga o Hønsa-Thórim, przeł. F. Kuklewski, Sandomierz 2009.

Saga o Njalu, przeł. A. Załuska-Strömberg, Poznań 1968.

Saga o Viga-Glumie, przeł. Ł. Malinowski, Sandomierz 2010.

Saga rodu z Laxdalu, przeł. A. Załuska-Strömberg, Poznań 1973.

\section{Opracowania}

Anderson E., Inclusive Masculinity. The Changing Nature of Masculinities, New York 2009.

Andersson T.M., The Displacement of the Heroic Ideal in the Family Sagas, „Speculum" 45 (1970), no. 4. 
Andersson T.M., The Growth of the Medieval Icelandic Sagas (1180-1280), New York 2006.

Andersson T.M., The Icelandic Family Saga. An Analytic Reading, Cambridge 1967.

Árnason V., Morality and Social Structure in the Icelandic Sagas, „The Journal of English and Germanic Philology" 2 (1991).

Auerbach L., Female Experience and Authorial Intention in Laxdæela saga, „Saga-Book of the Viking Society" 25 (1998-2001).

Bauman R., Performance and Honor in $13^{\text {th }}$-Century Iceland, „The Journal of American Folklore" 392 (1986).

Borovsky Z., Never in Public. Women and Performance in Old Norse Literature, „The Journal of American Folklore" 443 (1999).

Bourdieu P., Męska dominacja, przeł. L. Kopciewicz, Warszawa 2004.

Bullough V.L., On Being a Male in the Middle Ages, w: Medieval Masculinities. Regarding Men in the Middle Ages, ed. by C.A. Lees, Minneapolis 1994.

Byock J., Viking Age Iceland, London 2001.

Callow C., Transitions to Adulthood in Early Icelandic Society, w: Children, Childhood and Society, ed. by S. Crawford, G. Shepherd, Oxford 2007.

Charpentier Ljungqvist F., Rape in the Icelandic Sagas. An Insight in the Perceptions about Sexual Assaults on Women in the Old Norse World, „Journal of Family History" 4 (2015).

Ciklamini M., The Old Icelandic Duel, „Scandinavian Studies” 3 (1963).

Clover C.J., Hildigunnr's Lament, w: Cold Counsel. Women in Old Norse Literature and Mythology, ed. by S.M. Anderson, K. Swenson, New York 2002.

Clover C.J., Icelandic Family Sagas, w: Old Norse-Icelandic Literature. A Critical Guide, ed. by C.J. Clover, J. Lindow, New York 1985.

Clover C.J., Regardless of Sex. Men, Women, and Power in Early Northern Europe, „Representations” 44 (1993).

Connell R., Gender and Power. Society, the Person and Sexual Politics, Cambridge 1987.

Connell R., Masculinities, Berkeley 2005.

Connell R., Messerschmidt J.W., Hegemonic Masculinity. Rethinking the Concept, „Gender and Society” 6 (2005).

Danielli M., Initiation Ceremonial from Norse Literature, „Folklore” 2 (1945).

Demetriou D.Z., Connell's Concept of Hegemonic Masculinity. A Critique, „Theory and Society" 30 (2001), no. 3.

Donaldson M., What Is Hegemonic Masculinity?, „Theory and Society” 22 (1993), no. 5 (special issue: Masculinities).

Egilsdóttir Á., Masculinity and/or Peace? On Eyrbyggja saga’s Máhlíðingamál, w: Frederic Amory in Memoriam. Old Norse-Icelandic Studies, ed. by J. Lindow, G. Clark, Berkeley 2015.

Eliade M., Rites and Symbols of Initiation. The Mysteries of Birth and Rebirth, New York 1975. 
Evans G.L., Models of Men. The Construction and Problematization of Masculinities in the Islendingasögur, University of Oxford 2015.

Friðriksdóttir J.K., Gender, w: The Routledge Research Companion to the Medieval Icelandic Sagas, ed. by Á. Jakobsson, S. Jakobsson, New York 2017.

Friðriksdóttir J.K., Gender, Humor, and Power in Old Norse-Icelandic Literature, w: Laughter, Humor, and the (Un)Making of Gender. Historical and Cultural Perspectives, ed. by A. Foka, J. Liliequist, New York 2015.

Gennep A., van, Obrzędy przejścia. Systematyczne studium ceremonii, przeł. B. Biały, Warszawa 2006.

Goeres E.M., How to Do Things with Tears. The Funeral of Magnús inn góði, „Saga-Book of the Viking Society" 37 (2013).

Gogosz R., Horse-fights. The Brutal Entertainment of the Icelanders in the Middle Ages, „Średniowiecze Polskie i Powszechne” 5 (2013).

Gogosz R., Sagi o Islandczykach, w: Sagi islandzkie. Zarys dziejów literatury staronordyckiej, red. J. Morawiec, Ł. Neubauer, Warszawa 2015.

Hastrup K., Culture and History in Medieval Iceland. An Anthropological Analysis of Structure and Change, Oxford 1985.

Hermannsson H., Bibliography of the Icelandic Sagas and Minor Tales, Ithaca 1908.

Høyersten J.G., Madness in the Old Norse Society. Narratives and Ideas, „Nordic Journal of Psychiatry" 5 (2007).

Jakobsson Á., Egils saga and Empathy. Emotions and Moral Issues in a Dysfunctional Saga Family, „Scandinavian Studies” 1 (2008).

Jakobsson Á., Masculinity and Politics in Njáls saga, „Viator” 38 (2007).

Jakobsson Á., Troublesome Children in the Sagas of Icelanders, „Saga-Book of the Viking Society" 27 (2003).

Jakubczyk R., „Wielu, co go widzi, nie wie, czy to chtop czy niewiasta”, czyli o (nie) męskości w staroislandzkiej Sadze o Egilu i Sadze o Njalu, „Przegląd Humanistyczny" 2 (2018).

Jochens J., Women in Old Norse Society, Ithaca-London 1995.

Jones G., Some Characteristics of the Icelandic 'Hólmganga', „The Journal of English and Germanic Philology" 2 (1933).

Jorgensen Itnyre C., The Emotional Universe of Medieval Icelandic Fathers and Sons, w: Medieval Family Roles. A Book of Essays, ed. by C. Jorgensen Itnyre, New York 1996.

Judd W.E., Valgerðr's Smile, „Scandinavian Studies” 3 (1984).

Kaufman M., The Construction of Masculinity and the Triad of Men's Violence, w: Beyond Patriarchy. Essays by Men on Pleasure, Power, and Change, ed. by M. Kaufman, Toronto 1987.

Ker W.P., Epic and Romance. Essays on Medieval Literature, New York 1897.

Kress H., Taming the Shrew. The Rise of Patriarchy and the Subordination of the Feminine in Old Norse Literature, w: Cold Counsel. Women in Old Norse Literature and Mythology, ed. by S.M. Anderson, K. Swenson, New York 2002. 
Kress H., "You will find it all rather monotonous". On Literary Tradition and the Feminine Experience in Laxdoela saga, w: The Nordic Mind. Current Trends in Scandinavian Literary Criticism, ed. by F.E. Andersen, J. Weinstock, Lanham 1986.

Kristjánsson J., Var Snorri Sturluson upphafsmaður Íslendingasagna?, „Andvari” 32 (1990).

Laws of Early Iceland. Grágás, vol. 2, transl. by A. Dennis, P. Foote, R. Perkins, Winnipeg 2000.

Lönnroth L., Njáls saga. A Critical Introduction, Berkeley 1976.

Martin J.D., "Svá lýkr hér hverju hestaðingi". Sports and Games in Icelandic Saga Literature, „Scandinavian Studies” 1 (2003).

Meulengracht Sørensen P., Fortelling og are. Studier $i$ islandingesagaerne, Århus 1993.

Meulengracht Sørensen P., Social Institutions and Belief Systems of Medieval Iceland (c. 870-1400) and Their Relations to Literary Production, w: Old Icelandic Literature and Society, ed. by M. Clunies Ross, Cambridge 2000.

Meulengracht Sørensen P., The Unmanly Man. Concepts of Sexual Defamation in Early Northern Society, transl. by J. Turville-Petre, Odense 1983.

Miller W.I., Beating Up on Women and Old Men and Other Enormities. A Social Historical Inquiry into Literary Sources, „Mercer Law Review” 3 (1988).

Miller W.I., Humiliation and Other Essays on Honor, Social Discomfort, and Violence, Ithaca 1995.

Mills K., Grief, Gender, and Genre. Male Weeping in Snorri's Account of Baldr's Death, Kings' Sagas, and Gesta Danorum, „The Journal of English and Germanic Philology" 4 (2014).

Mundal E., The Position of Women in Old Norse Society and the Basis for their Power, „NORA. Nordic Journal of Feminist and Gender Research” 1 (1994).

Ólason V., Family Sagas, w: A Companion to Old Norse-Icelandic Literature and Culture, ed. by R. McTurk, Malden 2005.

Phelpstead C., Hair Today, Gone Tomorrow. Hair Loss, the Tonsure, and Masculinity in Medieval Iceland, „Scandinavian Studies” 1 (2013).

Phelpstead C., Size Matters. Penile Problems in Sagas of Icelanders, „Exemplaria” 3 (2007).

Pleck J.H., Men's Power with Women, Other Men, and Society. A Men's Movement Analysis, w: The Gender Gap in Psychotherapy. Social Realities and Psychological Processes, ed. by E.H. Carmen, P.P. Rieker, New York 1984.

Porter E., Manrique Antón T., Flushing in Anger, Blushing in Shame. Somatic Markers in Old Norse Emotional Expressions, „Cognitive Linguistic Studies” 2 (2015), no. 1.

Sayers W., Principled Women, Pressured Men. Nostalgia in Fljótsdæla saga, „Reading Medieval Studies" 22 (1996).

Stephens J., The Unwelcome Suitor. Patriarchal Norms, Masculine Inefficiency, and Negative Modelling in the Old Icelandic Kormáks saga, „Parergon” 2 (1992). 
Stieblin-Kamienski M., Ze świata sag, przeł. J. Litwiniuk, Warszawa 1982.

Ström F., Nið’, ergi, and Old Norse Moral Attitudes, London 1973.

Wanner K.J., Snorri Sturluson and the Edda. The Conversion of Cultural Capital in Medieval Scandinavia, Toronto 2008.

Williams M.W., Social Scandinavia in the Viking Age, New York 1920.

Wolf K., Somatic Semiotics. Emotions and the Human Face in the Sagas and poettir of Icelanders, „Traditio” 69 (2014). 